\title{
Seedling Performance Associated with Live or Herbicide Treated Tall Fescue
}

\author{
Jonathan J. Halvorson, ${ }^{1}$ David P. Belesky, ${ }^{2}$ and Harry W. Godwin ${ }^{3}$ \\ ${ }^{1}$ USDA-ARS Northern Great Plains Research Lab, Mandan, ND 58554, USA \\ ${ }^{2}$ Division of Plant \& Soil Sciences, West Virginia University, P.O. Box 6108, Morgantown, WV 26506, USA \\ ${ }^{3}$ USDA-ARS, Beaver, WV 25813-9423, USA \\ Correspondence should be addressed to Jonathan J. Halvorson; jonathan.halvorson@ars.usda.gov
}

Received 6 September 2014; Accepted 2 February 2015

Academic Editor: Iskender Tiryaki

Copyright (C) 2015 Jonathan J. Halvorson et al. This is an open access article distributed under the Creative Commons Attribution License, which permits unrestricted use, distribution, and reproduction in any medium, provided the original work is properly cited.

Tall fescue is an important forage grass which can host systemic fungal endophytes. The association of host grass and endophyte is known to influence herbivore behavior and host plant competition for resources. Establishing legumes into existing tall fescue sods is a desirable means to acquire nitrogen and enhance the nutritive value of forage for livestock production. Competition from existing tall fescue typically must be controlled to ensure interseeding success. We used a soil-on-agar method to determine if soil from intact, living (L), or an herbicide killed $(\mathrm{K})$ tall fescue sward influenced germination and seedling growth of three cultivars of tall fescue (E+, MaxQ, and E-) or legumes (alfalfa, red clover, and white clover). After 30 days, seedlings were larger and present in greater numbers when grown in $\mathrm{L}$ soil rather than $\mathrm{K}$ soil. Root growth of legumes (especially white clover) and tall fescue (especially MaxQ) were not as vigorous in $\mathrm{K}$ soil as L soil. While shoot biomass was similar for all cultivars of tall fescue in L soil, MaxQ produced less herbage when grown in K soil. Our data suggest establishing legumes or fescue cultivars may not be improved by first killing the existing fescue sod and seedling performance can exhibit significant interseasonal variation, related only to soil conditions.

Dedicated to M. M. H., requiescat in pace.

\section{Introduction}

Host grass-endophyte associations influence multiple above and belowground ecosystem processes [1-3]. Production of antiherbivory compounds by these associations, including an array of alkaloids in common pastures grasses such as perennial ryegrass (Lolium perenne L.) and tall fescue (Schedonorus arundinaceus (Schreb.) Dumort), is a wellknown phenomenon that has important agricultural [4, 5] and ecological implications [6-8]. The host-endophyte associations elicit responses in the canopy where the various classes of alkaloids act to ward off herbivory [9-12], and foliar diseases [13]. Responses also occur in the rhizosphere where the dynamics of mineral nutrients or toxicants are influenced by the associations [14-16]. The host-endophyte association also provides some resistance to soil-dwelling herbivores such as nematodes [17], which occurs despite localization of endophyte in the shoot of the host plant.

The rhizosphere response has been associated with the differential production of phenolic compounds [18]. These phenolic compounds and related flavonoids are bioactive and can function as plant growth regulators $[19,20]$. The associations influence accretion of carbon in the sward by affecting decomposition rates of senesced herbage, most likely through influences on soil microbial community processes [21-24]. Endophytes produce a range of bioactive products that can suppress the growth of other fungi such as arbuscular mycorrhizae [25]. Doing so could influence the microbial community of the soil environment of a newly sown stand and quite possibly alter the rate of seedling development 
and survival. This relationship has been approached from the perspective of allelopathic interactions of host-endophyte associations with cooccurring legumes [26], and forbs and tree species [27-31]. Some of the advantages of endophyte infection to the host plant might be manifested as increased herbage production conferring a competitive advantage over cooccurring plants in the sward $[1,14]$.

Renovating existing stands of endophyte-infected tall fescue often includes chemical elimination of the preexisting stand, sowing an annual crop, and then either respraying or sowing the desired replacement crop [32, 33]. Planting into a newly killed sod may present a challenge because of the effects of decomposing crop residues $[30,34]$ or carry-over herbicide effects especially where crop residues remain on the soil surface. Presumed allelopathic influences of hostendophyte associations could affect the success of renovating existing stands of endophyte-infected grasses or retard the success of attempts to interseed legumes into endophyteinfected stands as a means to ameliorate toxicity [35]. It could be that, upon the death of fescue-endophyte associations, the phenolic substances produced by the association are released into the soil and subsequently affect germination and plantmicrobe interactions, whereas if the integrity of the plant is not compromised in a living sward, the soluble constituents are retained in the existing structural components or leached out slowly [30, 36-38]. Including legumes in an infected tall fescue pasture can dilute or mask the effects of tall fescue grown alone but introducing legumes can sometimes prove difficult, particularly in well-established stands where competition for resources is strong [39]. Staley and Belesky [40] suggested that weak stands of forage legumes are probably not caused by inadequate nodulation but may instead be due to inhibition of root growth by detrimental physical/chemical conditions or allocation of limited photosynthate to shoots instead of roots in an establishing plant. Stephenson and Posler [41] reported seed germination and growth of birdsfoot trefoil (Lotus corniculatus L.) was significantly inhibited by tall fescue leaf extracts while Springer [28] reported clover germination and growth was inhibited by tall fescue seed extracts and Weston [42] found extracts of tall fescue residues were strongly inhibitory to weed seedling germination.

The objective of our work was to compare the germination and early seedling development of three pasture legumes planted in soil collected from a live or herbicide killed tall fescue sward. We hypothesized that establishing legumes in endophyte-infected fescue sods would improve with time after the sward was treated with herbicide. We also compared germination and early seedling development of tall fescue infected with either a naturalized endophyte or a nontoxic endophyte, or devoid of endophyte, in soil collected from live or glyphosate-killed tall fescue swards. Our premise was that endophyte infection would benefit tall fescue seedling establishment.

\section{Materials and Methods}

2.1. Study Site. The soil used in this assay was collected from $0-5 \mathrm{~cm}$ in a pasture located on a research farm in southern
West Virginia, USA $\left(37^{\circ} 47^{\prime} 55^{\prime \prime} \mathrm{N}, 80^{\circ} 58^{\prime} 19^{\prime \prime} \mathrm{W}\right)$. Soil was classified as a fine loamy, mixed, mesic Typic Hapludult (Soil Survey Staff, 2010) and contained 3.8\% and 0.38\% total carbon and nitrogen, respectively, and had a $\mathrm{pH}(1: 1$ soil to water) of 6 (Jonathan Halvorson, personal communication). Initial plant cover consisted almost exclusively of endophyteinfected, tall fescue (presumed to be the widely-grown "KY31 ") that had been managed as a hayfield and cattle pasture for at least 30 years. The pasture was bisected into two equally sized areas prior to the experiment and on 26 May 2003; one block of about 0.3 ha was treated with the nonselective herbicide glyphosate [N-(phosphonomethyl)glycine] at $7 \mathrm{~L} /$ ha to eradicate the existing stand that was predominantly tall fescue. Subsequent herbicide applications were made at the same rate of application on 21 August 2003 and 9 June 2004 to control regrowth. The senescing herbage was allowed to remain on the glyphosate-treated areas. Herbage on the untreated areas was allowed to grow undisturbed.

Samples of surface soil were collected periodically from the intact, untreated sward (L), and the glyphosate-treated (K) areas for use in the soil-on-agar bioassay microcosm experiments. On each sample day, 12 soil cores $(6.35 \mathrm{~cm}$ diameter) were collected near marked locations in each area and composited. Composited samples were sieved to pass a $2 \mathrm{~mm}$ opening screen and maintained in plastic bags at $4^{\circ} \mathrm{C}$ until used in the bioassays.

Samples collected on 26 June, 29 July, 10 September, 30 October, 30 December 2003, and 29 March, 21 May, and 8 July 2004 were used within 10 days of collection to determine temporal patterns of germination and early seedling development of three pasture legumes: alfalfa (Medicago sativa L. cv. Alfagraze), red clover, (Trifolium pratense cv. Cinnamon), and white clover (Trifolium repens cv. Grasslands Huia). Seed mass of these legumes averaged 3.18, 1.87 , and $0.66 \mathrm{mg} \mathrm{seed}^{-1}$, respectively. Soil collected on 29 March 2004 was used to compare the influence of $\mathrm{L}$ and $\mathrm{K}$ sod on 3 cultivars of tall fescue, S. arundinaceus (formerly Festuca arundinacea Schreb.) cv. Jesup+ (E+), infected by Epichloë coenophiala (formerly Neotyphodium coenophialum), cv. Jesup- (E-), an endophyte-free variety, and cv. Jesup Max-Q (NE), containing the novel endophyte AR542 (cf. [5]).

2.2. Soil-on-Agar Bioassay. We used the soil-on-agar method $[43,44]$ to determine effects of soil associated with $\mathrm{L}$ and $\mathrm{K}$ tall fescue sod on seedling root elongation and plant biomass (Figure 1). Polystyrene tissue culture flasks (260 mL capacity) were cut off at the $250 \mathrm{~mL}$ mark. To each flask $200 \mathrm{~mL}$ of $0.5 \%$ sterile water agar, allowed to stabilize overnight, was added. The next day, $25 \mathrm{~g}$ oven-dry equivalent of field moist test soil was layered (lightly pressed) on top of agar creating a layer about $0.8-1.0 \mathrm{~cm}$ thick. Eighteen seeds of a given plant species were placed in three evenly spaced rows of six seeds on top of the soil in a flask. Each plant species by soil type combination was replicated 7 times. Seeds were covered (lightly pressed) with $15 \mathrm{~g}$ test soil (depth $0.4-0.5 \mathrm{~cm}$ ). Flasks, on trays, were maintained in a Hoffman controlled environment chamber (model SG50SS) at a 14/10 light/dark photoperiod, light intensity $450 \mathrm{mmol} \mathrm{m}^{-2} \mathrm{~s}^{-1}, 23 / 17^{\circ} \mathrm{C}$, and $50 \%$ relative 


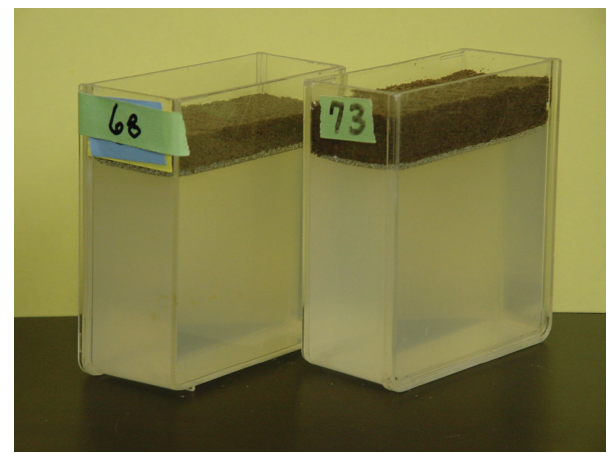

FIGURE 1: The soil-on-agar assay: a thin layer of field-moist soil is uniformly distributed on top of solidified water agar $\left(5 \mathrm{~g} \mathrm{~kg}^{-1}\right.$ agar in distilled water) in a rectangular, clear-plastic flask. Seeds are planted and covered with a layer of soil. Initial root or shoot growth can be monitored and plants can be maintained for other measurements.

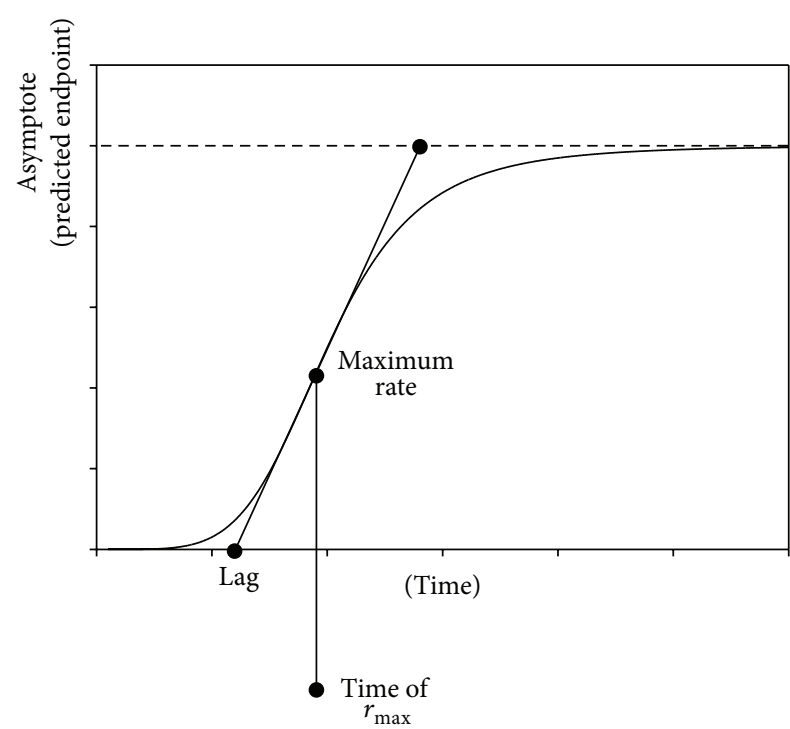

FIGURE 2: Schematic of modified Gompertz curve (modified from [45]).

humidity, for the duration of the experiment. Trays were rotated and relocated within chambers daily. The number of roots emerging from the soil into the agar was recorded periodically. Emergence data were fit to a modified Gompertz model [45] using nonlinear least squares and TableCurve 2D v5.01 (SYSTAT Software Inc., San Jose, CA) to estimate time of first root emergence from the soil layer into the agar (lag) and the final number of elongating roots (i.e., the asymptote of the emergence curve) (Figure 2). After approximately $30 \mathrm{~d}$, plants growing in flasks were harvested, dried to a constant weight, and assayed for biomass and root to shoot ratios. To facilitate comparisons among dates, values for biomass were normalized to a constant reference time (30 days).

2.3. Statistical Analyses. Significant differences between soil treatments and changes with time were determined by analysis of variance (ANOVA) using SAS 9.2 and PROC MIXED with a model that accounted for fixed (treatment)

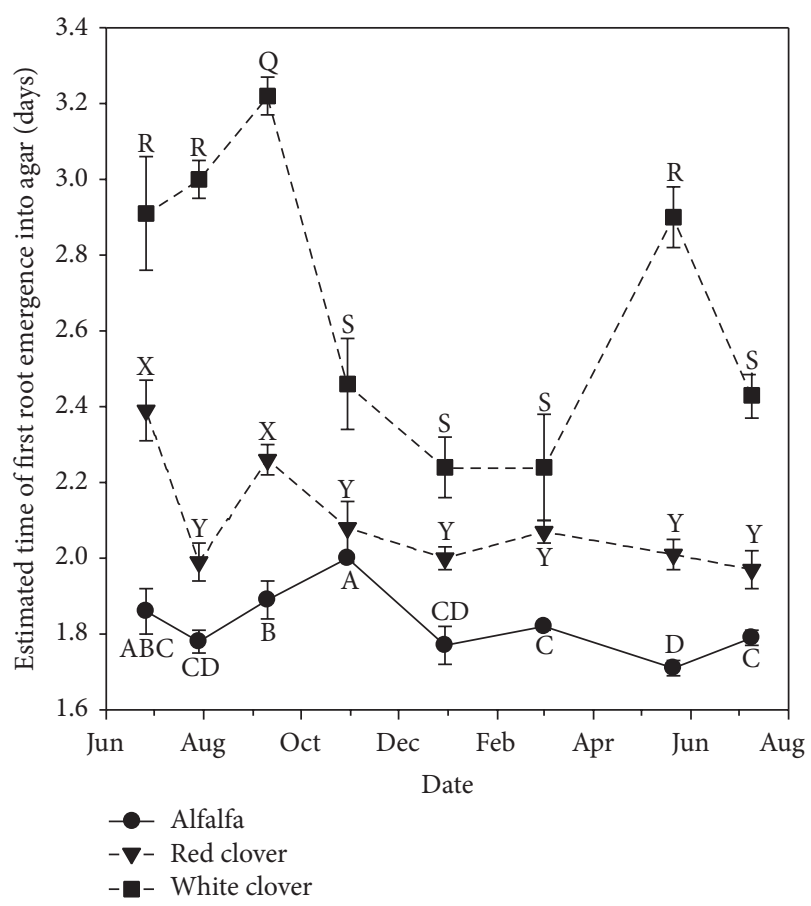

Figure 3: Time to first root emergence into agar (lag) estimated with modified Gompertz curves (mean, SEM, and $n=7$ ). For each legume, significant main effects of sample date are denoted by upper case letters determined with a protected LSD $(P<0.05)$.

and random (sample location) effects and treated sample date as a repeated measure [46, 47]. The KR (KenwardRoger) option was used to calculate degrees of freedom while covariance structures were selected to minimize Akaike's Information Criterion. Multiple pairwise comparisons of means were performed using the Protected LSD method and a value of $5 \%$ (i.e., $P<0.05$ ) as the minimum criterion for significance. Assumptions of normality were evaluated and appropriate data transformations were identified with SAS/ASSIST. Values indicated in text and graphs are the arithmetic mean, \pm the standard error of the mean, expressed on oven-dry soil basis.

\section{Results}

3.1. Legume Growth Patterns. Patterns of root emergence were described by modified Gompertz models with coefficients of determination, $\left(r^{2}\right) \geq 0.99$ for each of the three legume species. The amount of time (lag) between planting and first emergence of roots through the soil layer differed among legumes with alfalfa seedlings emerging faster than red clover or white clover. The lags for each legume varied significantly with date $(P<0.0001)$ but interseasonal patterns were most pronounced for white clover with slowest root emergence occurring during the growing season compared to emergence in soil collected during the fall and winter months (Figure 3). Lag times did not differ between soil from $\mathrm{L}$ and $\mathrm{K}$ sods for alfalfa or red clover seedlings, but lag times for 


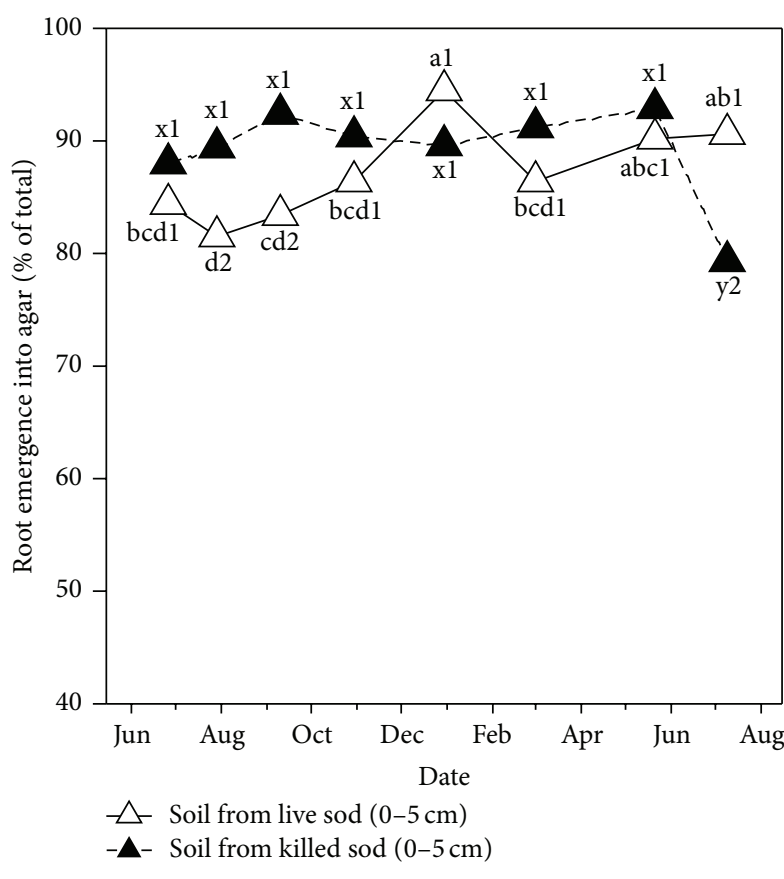

(a) Alfalfa

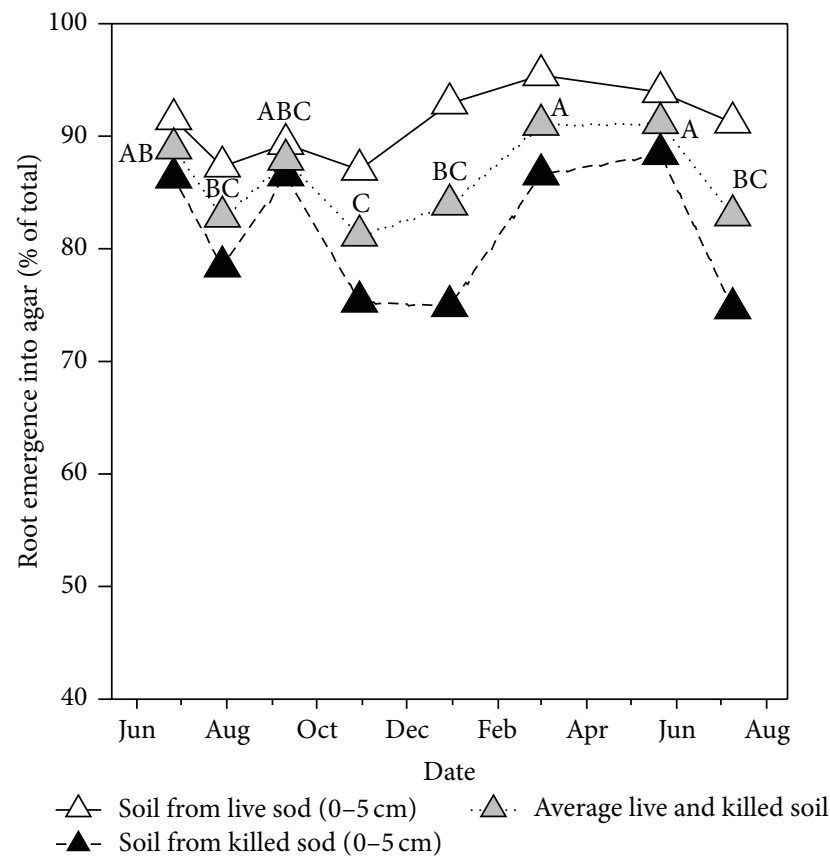

(b) Red clover

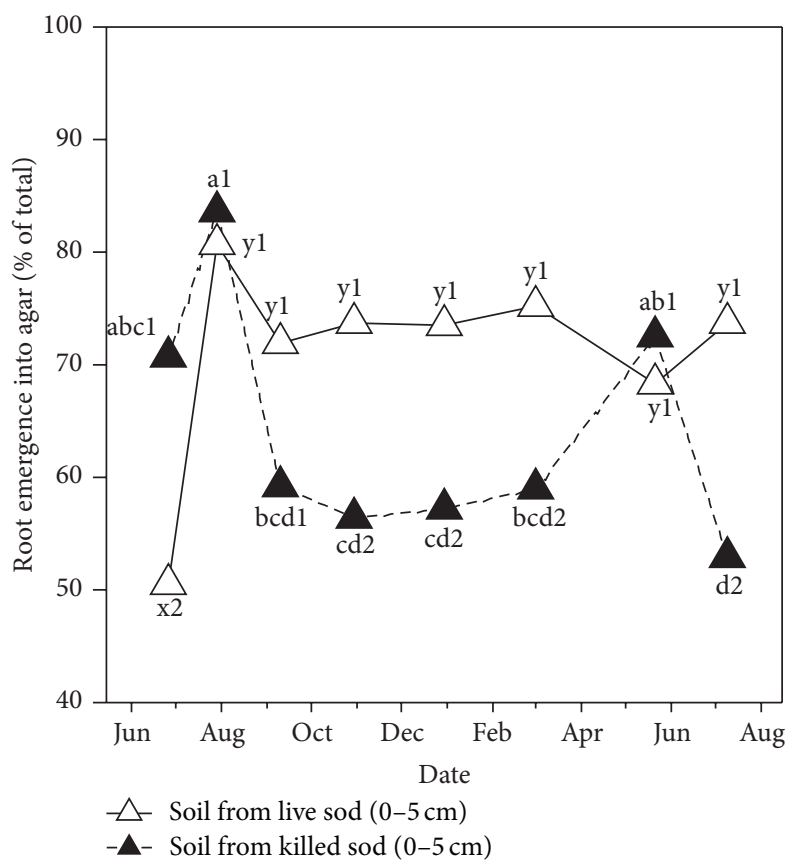

(c) White clover

FIGURE 4: Average root emergence into agar $(n=7)$. For significant interactions observed for alfalfa and white clover, differences among sample dates are denoted by lower case letters while differences between soil from a living intact tall fescue sward (L) and soil from a glyphosate-killed tall fescue sward $(\mathrm{K})$ are denoted with numbers. Significant main effects of date for red clover are depicted by upper case letters.

white clover were significantly greater $(P \leq 0.001)$ in $\mathrm{L}$ $(2.79 \pm 0.07 \mathrm{~d})$ than $\mathrm{K}(2.57 \pm 0.06 \mathrm{~d})$ conditions.

Percent root emergence, determined from the mean asymptote of Gompertz models, varied significantly for alfalfa as an interaction between soil treatments and sampling date $(P \leq 0.005)$. However, the pattern of root emergence for each sample date indicated little practical difference between soil treatment or sampling dates and an overall average for root emergence of $88.2 \pm 0.7 \%$ (Figure $4(\mathrm{a})$ ). Emergence of red clover roots was significantly greater $(P \leq 0.0001)$ in $\mathrm{L}$, $91.1 \pm 0.9 \%$, compared to $K, 81.4 \pm 1.6 \%$, and also varied with sample date $(P \leq 0.05)$, being greatest in spring, where 


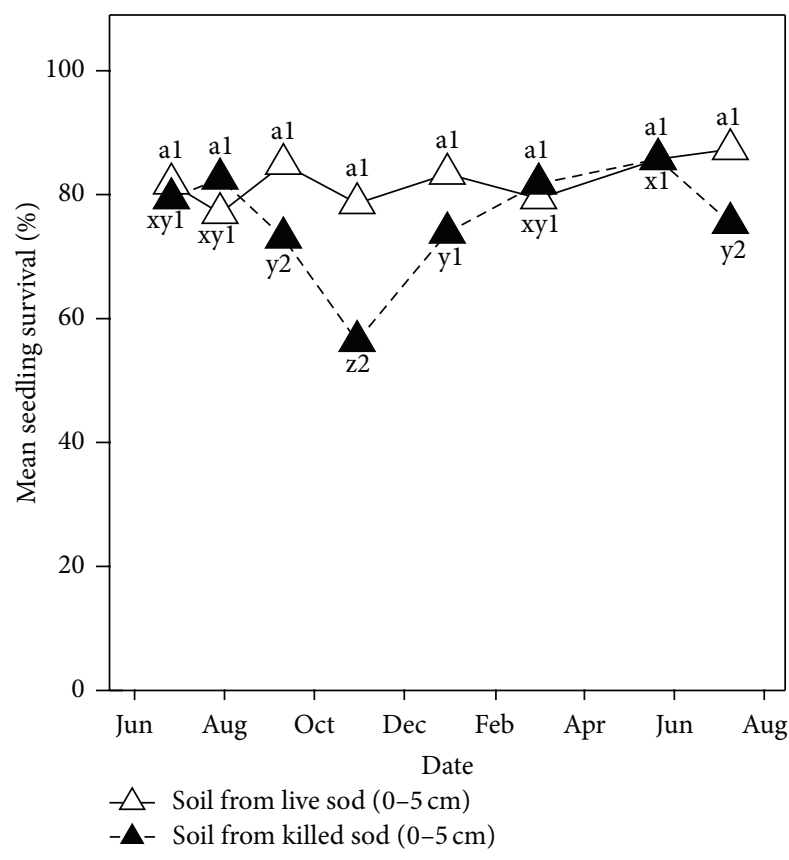

(a) Alfalfa

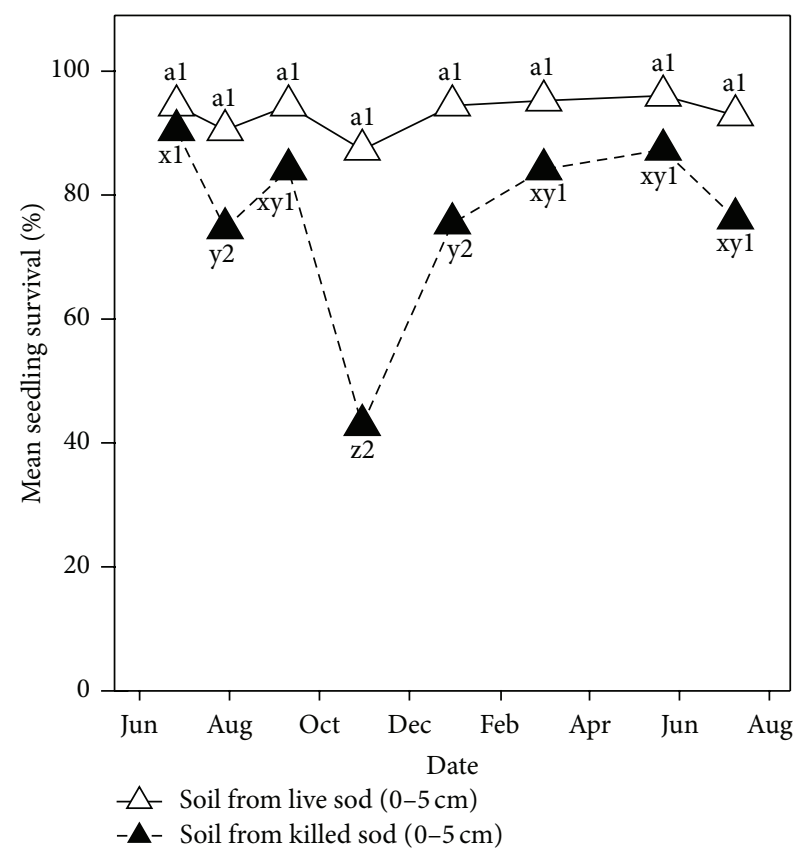

(b) Red clover

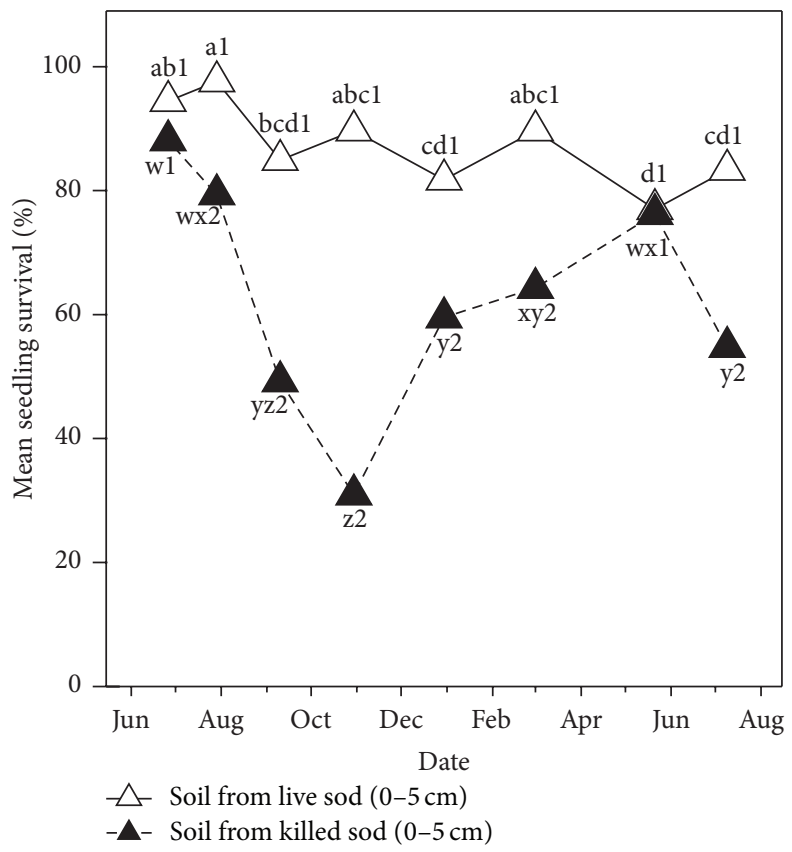

(c) White clover

Figure 5: Average final seedling survival $(n=7)$. Significant interactions denoted as in Figure 4.

emergence approached $90 \%$, and least during the winter months with most of the variation observed when grown in soil collected from the K treatment (Figure 4(b)). Root emergence for white clover varied as an interaction between sample date and treatment $(P \leq 0.0001)$. With the exception of the first harvest date, white clover root emergence of plants growing in soil from the L treatment did not vary with harvest date (Figure 4(c)). Conversely, root emergence for white clover in $\mathrm{K}$ exhibited evidence of seasonal variation with lowest emergence in soil collected during fall and winter, significantly less than in $\mathrm{L}$ derived soil.

Seedling survival at the end of the experiment varied for each of the three legume species as an interaction between soil treatment and sampling date $(P \leq 0.01)$. In $\mathrm{L}$ soil, survival remained relatively high and did not vary with sample date for both alfalfa and red clover, averaging $82.2 \pm 1.8$ and $93.1 \pm$ $1.0 \%$, respectively (Figures 5(a) and 5(b)). Survival of white clover seedlings exhibited a similar pattern and was relatively 


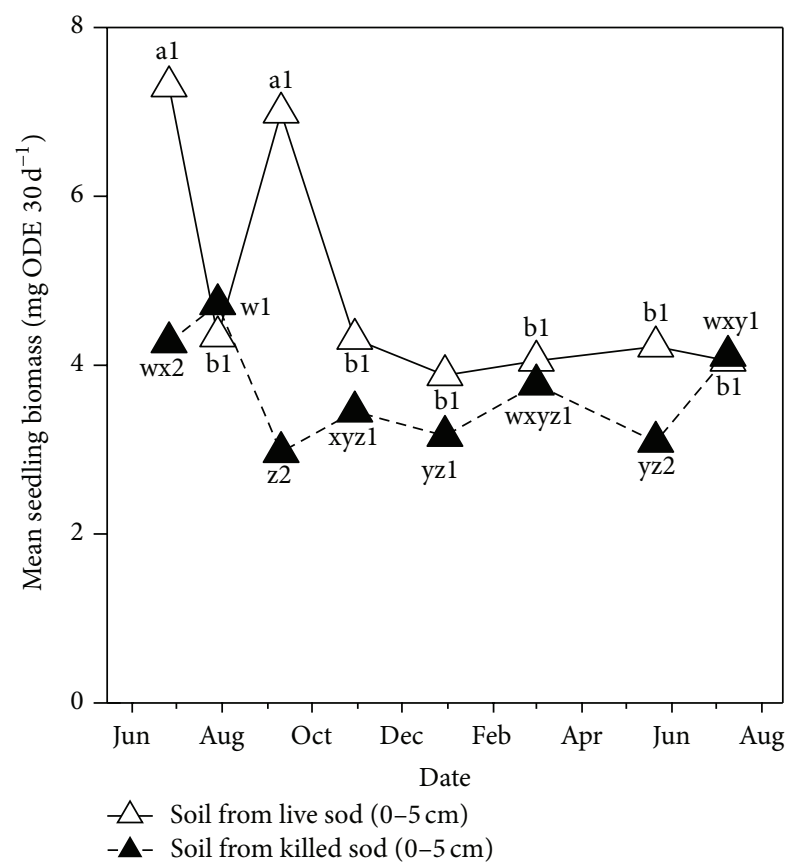

(a) Alfalfa

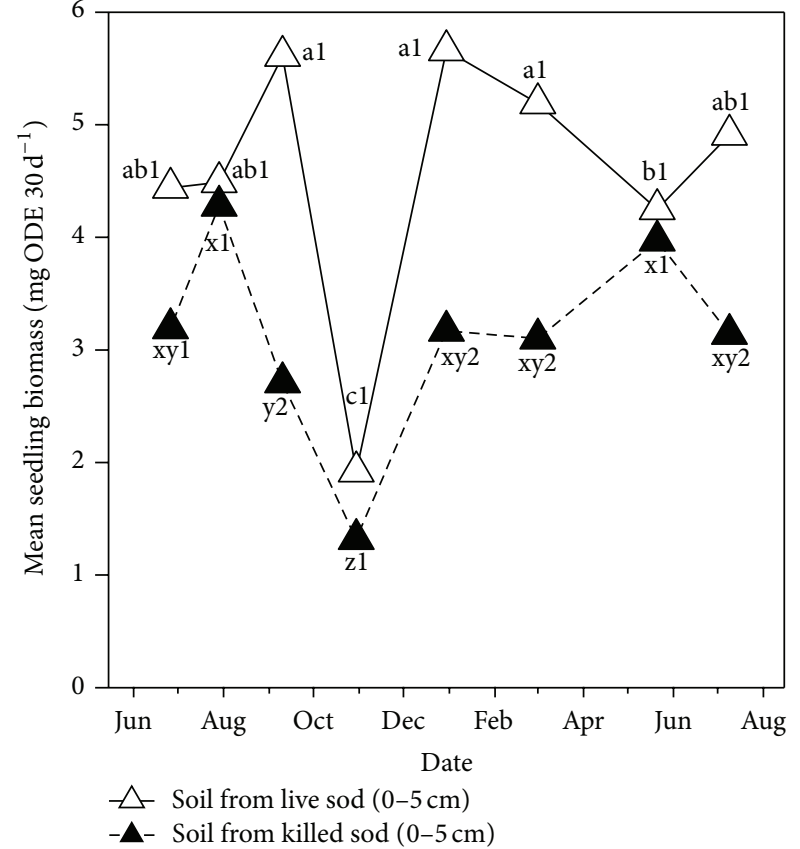

(b) Red clover

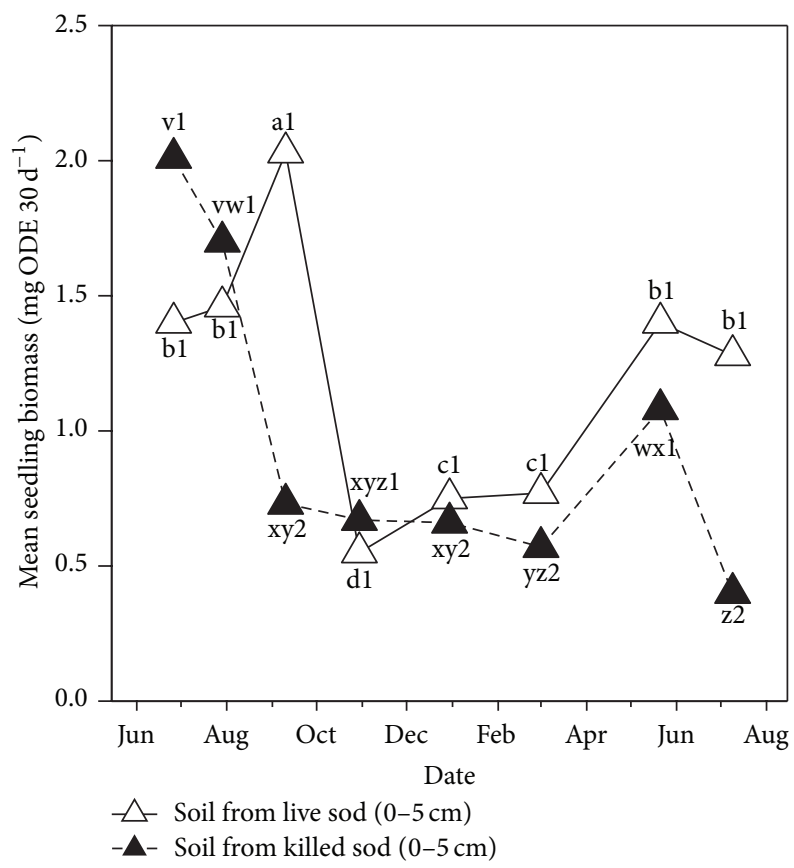

(c) White clover

FIGURE 6: Average seedling biomass normalized to a 30 day value $(n=7)$. Significant interactions denoted as in Figure 4.

constant $(87.3 \pm 1.6 \%)$ but also tended to decrease slightly with time (Figure 5(c)). In contrast, seedlings of each legume species exhibited significantly lower survival when planted in K soil collected during fall and winter months, a pattern that appeared most pronounced for white clover.

Final seedling dry mass also varied as an interaction between soil type and date $(P \leq 0.001)$. Average alfalfa dry mass generally declined with sample date but did not exhibit a clear seasonal effect (Figure 6(a)). Conversely, significant interseasonal variation in average seedling dry mass was observed for red and especially white clover with smaller seedlings produced from soil collected in fall and winter compared to those grown in soil collected during the growing season (Figures 6(b) and 6(c)). Seedling biomass was greater in soil from the $\mathrm{L}$ than $\mathrm{K}$ treatment for each of the legume species $(P \leq 0.0001)$. 


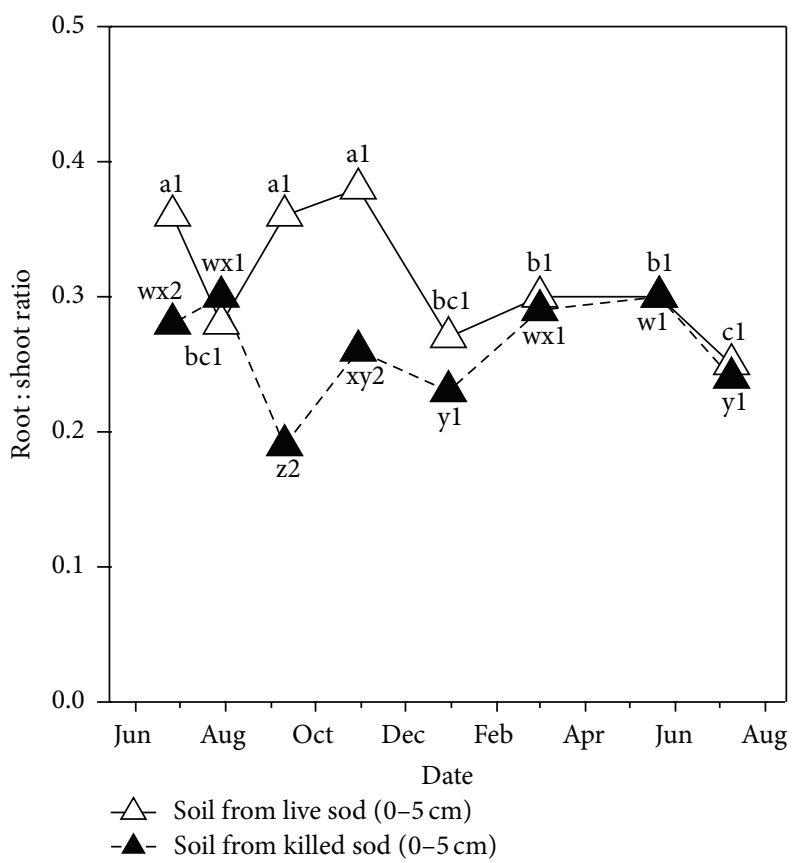

(a) Alfalfa

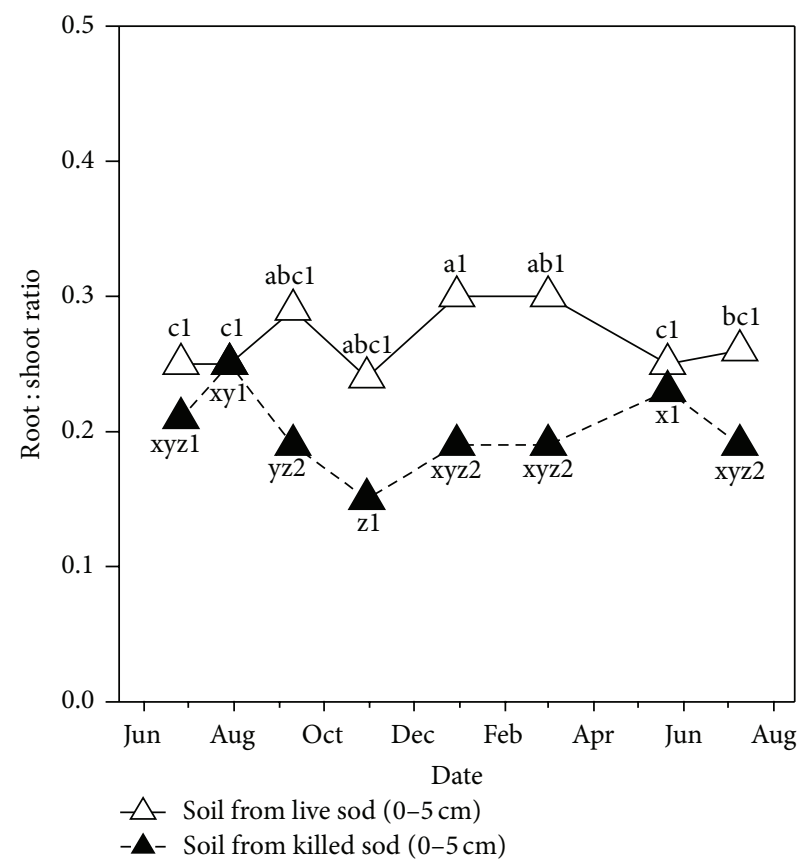

(b) Red clover

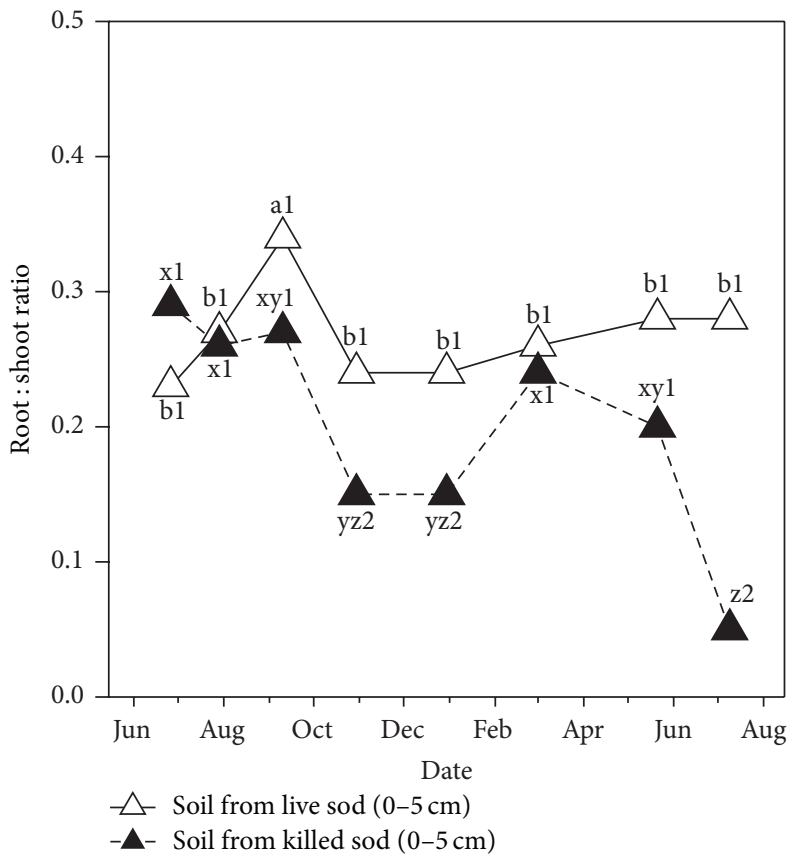

(c) White clover

Figure 7: Average seedling root: shoot mass ratios $(n=7)$. Significant interactions denoted as in Figure 4.

Like other seedling characteristics, root to shoot ratios calculated for each legume varied as an interaction between soil type and date $(P \leq 0.01)$. Ratios were generally lower in $\mathrm{K}$ than L-soil grown plants, but significant differences between the two soil treatments were most apparent for red and white clover especially when grown in soil collected in fall and winter (Figure 7).
3.2. Effects of Fescue-Endophyte Associations. Modified Gompertz curves explained more than $98 \%$ of the patterns of fescue root emergence and indicated a mean lag time to first emergence of $3.5 \pm 0.1 \mathrm{~d}$ for all cultivars. However, the percentage of roots visible in agar after 10 days varied significantly with fescue cultivar $(P<0.0001)$ and soil treatment $(P<0.05)$ (Figure $8(\mathrm{a}))$. Percent root emergence 


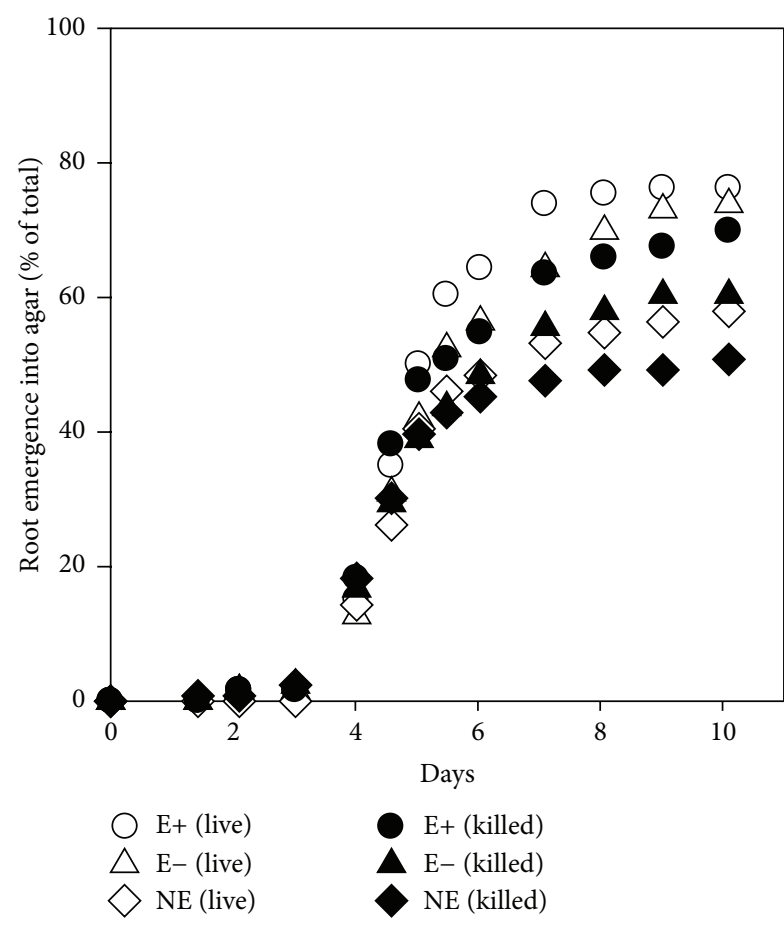

(a)

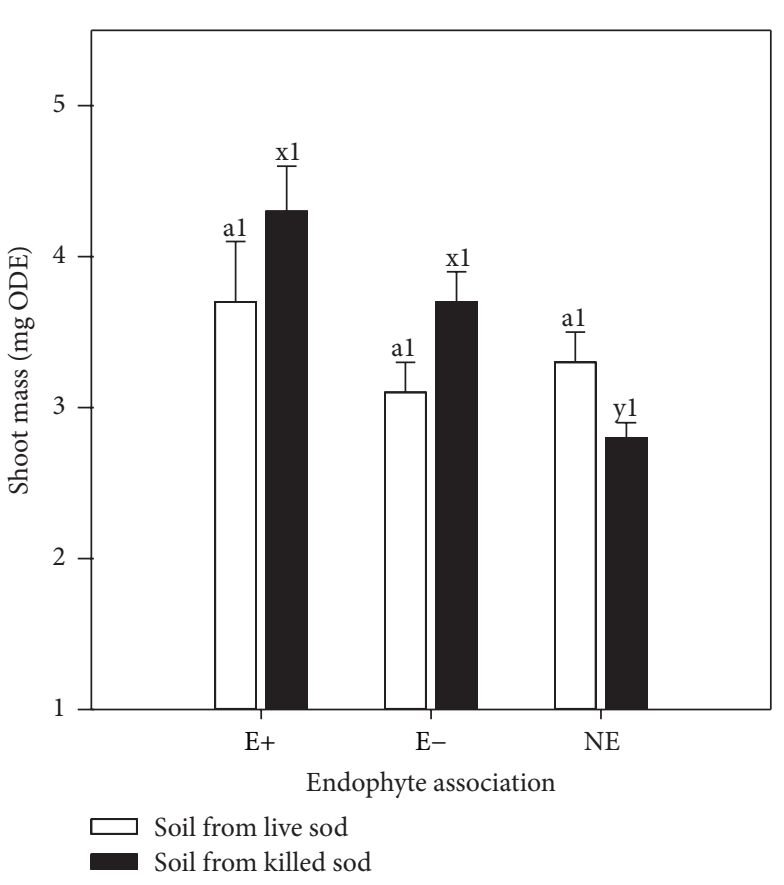

(b)

FIGURE 8: Patterns of (a) root emergence after 10 days and (b) average shoot biomass normalized to a 30-day value (mean, SEM, $n=7$ ) for Jesup tall fescue infected with naturalized endophyte (E+), a novel endophyte, Max Q, AR542, (NE), or noninfected (E-) grown in soil from a living intact tall fescue sward (L) or in soil from a glyphosate-killed tall fescue sward (K). Significant interactions denoted as in Figure 4.

for $\mathrm{E}+$ and $\mathrm{E}-$ tall fescue cultivars was similar, $73.0 \pm 2.2 \%$ and $67.1 \pm 4.8 \%$, respectively, and both were greater than that attained by $\mathrm{NE}$ tall fescue plants $(54.4 \pm 4.4 \%)$. A greater percentage of roots emerged into agar when tall fescue was grown in $\mathrm{L}$ soil $(69.3 \pm 3.6 \%)$ compared to $\mathrm{K}$ soil $(60.3 \pm 3.4 \%)$. Actual root emergence observed at 10 days was not significantly different compared to the asymptote values predicted by the Gompertz models. There was some indication that shoot growth at 10 days was also affected by soil treatment $(P<0.07)$ with $86.8 \pm 2.0 \%$ of the shoots emerging from $\mathrm{L}$ treatment soil compared to $81.2 \pm 1.9 \%$ from $\mathrm{K}$ treatment soil. However, shoot counts at final harvest (29 days) did not vary significantly among fescue cultivars or treatment and averaged $86.6 \pm 1.3 \%$.

Shoot biomass at final harvest varied with cultivar $(P<$ $0.005)$ and as an interaction between cultivar and soil type $(P<0.05)$. Greatest average biomass was observed for the $\mathrm{E}+$ cultivar, $4.0 \pm 0.2 \mathrm{mg}$, compared to either $\mathrm{E}-$ or NE, $3.4 \pm 0.2$ and $3.0 \pm 0.2 \mathrm{mg}$, respectively. The interaction revealed that each cultivar produced similar biomass when planted in L soil but that the NE cultivar produced significantly less biomass than either the $\mathrm{E}+$ or $\mathrm{E}-$ cultivar when grown in $\mathrm{K}$ soil (Figure 8(b)).

\section{Discussion}

Results and opinions are mixed concerning how hostendophyte associations influence the success of seeding legumes into existing tall fescue swards [37, 48]. General agronomic practices and recommendations are to suppress or destroy the existing sward to lessen the influence of competition from an intact tall fescue stand and then sow legumes [49]. Recent work suggests that removal of residual tall fescue biomass before sowing is more important than seeding method $[32,33]$.

Contrary to our expectations, soil characteristics that favor legume seedling establishment and early growth did not develop in soil after infected tall fescue was suppressed by glyphosate. Instead, fewer, smaller seedlings developed in soil derived from the $\mathrm{K}$ treatment than in soil collected from areas where intact living tall fescue was maintained. This was associated with subjective observations of more damping off in seedlings germinating in soil from the $\mathrm{K}$ treatment. Thus, our findings support observations that living tall fescue swards stabilize or buffer conditions associated with soil-dwelling organisms that might feed on establishing seedlings [12] or soil pathogens. Infection with Neotyphodium endophytes has been associated with the production of phenolic substances and volatile organic compounds in tall fescue and perennial ryegrass that reduce the effects of fungal pathogens such as Rhizoctonia zeae and Fusarium poae $[50,51]$. Our data suggest live tall fescue sods may confer substances to soil that mitigate the effects of pathogenic microorganisms. Intact sods might retain soluble allelopathic constituents in living plant tissues that might otherwise be released to the soil by dead and decaying tissues, which are likely to have relatively long-term 
influences on soil biota [30]. Consequently, the prospect of a legacy effect associated with a suppressed sod has definite ecological and applied agronomic implications. From the practical perspective, it might be better to overseed or frost seed legumes into a live tall fescue sod and avoid having to incur the economic and environmental costs associated with herbicide use. Conditions in the live tall fescue sod may be less inhospitable to establishing legume seedlings than conditions associated with decomposing tall fescue shoot and root tissue. A live tall fescue canopy can benefit from nitrogen fixed by legumes; consequently, vigorously growing companion grasses including tall fescue have little to gain by suppressing legume establishment.

We also observed clear seasonal variations of seedling performance, despite controlled assay conditions, especially when grown in soil from the glyphosate-killed sward treatment. This response suggests innate soil conditions that influence seed germination growth are dynamic with a legacy effect that can persist; perhaps this is related to interactions with soil microorganisms or decomposition of plant residues [52]. We observed times during the year when seedling performance was not influenced by soil treatment, while at other times, especially autumn-winter, soil from the $\mathrm{K}$ treatment deterred seedling performance (namely, Figures 4(c), 5, and 7). Seasonal patterns of seedling root growth, survival, and root to shoot ratios were less apparent in L soil suggesting conditions associated with a living, intact tall fescue sward may either suppress or buffer soil biota-related stresses.

Our data demonstrate strong interspecific differences among legumes for seedling vigor and sensitivity to soil treatment with most rapid germination and least seasonal variation observed for alfalfa, intermediate for red clover and relatively slow germination and greatest interseasonal variation for white clover. This suggests that producers need to be mindful of what plants might work for their situation. Overseeding with alfalfa might be the most likely choice for successful renovation of a tall fescue sward [53]. Ultimately, the end-use of the sward will dictate what is sown.

The responses we obtained validate published observations indicating that tall fescue hosting novel endophyte AR542 tends to grow at a slower rate than congenerics devoid of or hosting the native endophyte $[54,55]$. Better root growth for all cultivars and no variations in shoot biomass observed in plants growing in L soil are consistent with the hypothesis that live fescue swards suppress or control conditions that otherwise hinder seedlings, such as pathogens, or alternatively suggest a level of nutrient availability different from that in the glyphosate-killed sod soils. Conversely, root growth was suppressed in $\mathrm{K}$ soil and stem mass of tall fescue hosting the novel endophyte AR 542 was less than that of congenerics despite reports that the novel host-endophyte association allocates a greater amount of photosynthate to shoot growth [54]. These patterns are consistent with the presence of allelopathic decomposition products or pathogens thriving in the glyphosate-killed sod that could affect seed germination and seedling health.

In this experiment plant genotype was uniform but endophyte-association varied, suggesting endophytes influence early seedling development and adaptability to conditions associated with management of existing tall fescue herbage. Thus sowing an array of tall fescue host-endophyte associations (typical of open-pollinated cultivars) into glyphosatekilled sod would have highly variable success in terms of seedling growth. In addition actively growing tall fescue may be allelopathic or autotoxic to seedlings.

\section{Conclusions}

Results from microcosm soil tests suggest efforts to improve tall fescue pastures by introducing legumes or fescue cultivars with novel fungal associations are not favored by first killing the existing fescue sod. Instead, seedling performance may be inhibited by conditions associated with soil from killed tall fescue such as herbicide residue, plant decomposition products, or presence of disease organisms and insects, although these aspects were not quantified at this time. The data also indicate that seedling performance in fescue sods can exhibit significant variation among soil sampling dates, related to soil conditions, independent of climatic conditions influencing plant growth.

We studied the establishment of small-seeded legumes and fescue congenerics into live or killed tall fescue soil from an agronomic perspective and viewed the plant as an integrator of environmental and edaphic features. However, we recognize that underlying simplistic system responses we observed are numerous interacting factors. Thus more work should be done to distinguish between inherent seasonal patterns and treatment effects on biotic and abiotic soil characteristics that affect establishment, productivity, and persistence of desirable species in forage mixtures. These include patterns of nutrient availability, identification and quantification of allelopathic compounds such as alkaloids and phenolic compounds, and characterization of soil microbial community structure and function, especially pathogenic organisms. We cannot yet surmise how long the patterns we observed in our studies persist; however, if the results from the microcosm work can be verified under field conditions, avoiding the use of herbicides complies with and facilitates organic agricultural practice and reduces expenses and environmental concerns in conventional production systems.

\section{Disclosure}

Harry W. Godwin is currently retired.

\section{Disclaimer}

USDA is an equal opportunity provider and employer. Mention of trade names or commercial products in this paper is solely for the purpose of providing specific information and does not imply recommendation or endorsement by the United States Department of Agriculture.

\section{Conflict of Interests}

The authors declare that there is no conflict of interests regarding the publication of this paper. 


\section{Acknowledgments}

The authors thank B. Harter, K. O’Neill, J. Mandeville, T. Robertson, J. Ruckle, and D. Ruckle for excellent assistance in collection and analysis of data. The paper was improved by the thoughtful comments of anonymous reviewers.

\section{References}

[1] R. J. Rodriguez, J. F. White Jr., A. E. Arnold, and R. S. Redman, "Fungal endophytes: diversity and functional roles," New Phytologist, vol. 182, no. 2, pp. 314-330, 2009.

[2] M. S. Torres, J. F. White, X. Zhang, D. M. Hinton, and C. W. Bacon, "Endophyte-mediated adjustments in host morphology and physiology and effects on host fitness traits in grasses," Fungal Ecology, vol. 5, no. 3, pp. 322-330, 2012.

[3] G. P. Cheplick and S. H. Faeth, Ecology and Evolution of the Grass-Endophyte Symbiosis, Oxford University Press, Oxford, UK, 2009.

[4] D. P. Malinowski and D. P. Belesky, "Ecological importance of Neotyphodium spp. grass endophytes in agroecosystems," Grassland Science, vol. 52, no. 1, pp. 1-14, 2006.

[5] C. A. Young, D. E. Hume, and R. L. Mcculley, "Forages and pastures symposium: fungal endophytes of tall fescue and perennial ryegrass: Pasture friend or foe?" Journal of Animal Science, vol. 91, no. 5, pp. 2379-2394, 2013.

[6] M. Omacini, M. Semmartin, L. I. Pérez, and P. E. Gundel, "Grass-endophyte symbiosis: a neglected aboveground interaction with multiple belowground consequences," Applied Soil Ecology, vol. 61, pp. 273-279, 2012.

[7] L. P. Singh, S. S. Gill, and N. Tuteja, "Unraveling the role of fungal symbionts in plant abiotic stress tolerance," Plant Signaling and Behavior, vol. 6, no. 2, pp. 175-191, 2011.

[8] J. A. Rudgers, J. M. Koslow, and K. Clay, "Endophytic fungi alter relationships between diversity and ecosystem properties," Ecology Letters, vol. 7, no. 1, pp. 42-51, 2004.

[9] K. M. Crawford, J. M. Land, and J. A. Rudgers, "Fungal endophytes of native grasses decrease insect herbivore preference and performance," Oecologia, vol. 164, no. 2, pp. 431-444, 2010.

[10] K. Saikkonen, P. E. Gundel, and M. Helander, "Chemical ecology mediated by fungal endophytes in grasses," Journal of Chemical Ecology, vol. 39, no. 7, pp. 962-968, 2013.

[11] A. Raman, W. Wheatley, and A. Popay, "Endophytic fungusvascular plant-insect interactions," Environmental Entomology, vol. 41, no. 3, pp. 433-447, 2012.

[12] M. Czarnoleski, P. Olejniczak, P. Mikołajczak, M. Lembicz, and J. Kozłowski, "Fungal endophytes protect grass seedlings against herbivory and allow economical seed production," Evolutionary Ecology Research, vol. 12, no. 6, pp. 769-777, 2010.

[13] G. C. Latch, "Diseases and endophytes," in Tall Fescue for the Twenty-First Century, vol. 53 of Agron. Monogr, pp. 121-128, 2009.

[14] D. P. Malinowski, D. P. Belesky, and J. M. Fedders, "Endophyte infection may affect the competitive ability of tall fescue grown with red clover," Journal of Agronomy and Crop Science, vol. 183, no. 2, pp. 91-101, 1999.

[15] D. P. Belesky and C. P. West, "Abiotic stresses and endophyte effects," in Tall Fescue for the Twenty-First Century, H. A. Fribourg, D. B. Hannaway, and C. P. West, Eds., Agronomy Monographs 53, pp. 49-64, American Society of Agronomy, Crop Science Society of America, Soil Science Society of America, Madison, Wis, USA, 2009.
[16] M. M. Van Hecke, A. M. Treonis, and J. R. Kaufman, "How does the fungal endophyte Neotyphodium coenophialum affect tall fescue (Festuca arundinacea) rhizodeposition and soil microorganisms?" Plant and Soil, vol. 275, no. 1-2, pp. 101-109, 2005.

[17] A. A. Bacetty, M. E. Snook, A. E. Glenn et al., "Toxicity of endophyte-infected tall fescue alkaloids and grass metabolites on Pratylenchus scribneri," Phytopathology, vol. 99, no. 12, pp. 1336-1345, 2009.

[18] D. P. Malinowski, G. A. Alloush, and D. P. Belesky, "Evidence for chemical changes on the root surface of tall fescue in response to infection with the fungal endophyte Neotyphodium coenophialum," Plant and Soil, vol. 205, no. 1, pp. 1-12, 1998.

[19] T. Yoshioka, T. Inokuchi, S. Fujioka, and Y. Kimura, "Phenolic compounds and flavonoids as plant growth regulators from fruit and leaf of Vitex rotundifolia," Zeitschrift fur Naturforschung, Section C, vol. 59, no. 7-8, pp. 509-514, 2004.

[20] A. H. Aly, A. Debbab, and P. Proksch, "Fungal endophytes: unique plant inhabitants with great promises," Applied Microbiology and Biotechnology, vol. 90, no. 6, pp. 1829-1845, 2011.

[21] M. Omacini, E. J. Chaneton, C. M. Ghersa, and P. Otero, "Do foliar endophytes affect grass litter decomposition? A microcosm approach using Lolium multiflorum," Oikos, vol. 104, no. 3, pp. 581-590, 2004.

[22] A. J. Franzluebbers, N. Nazih, J. A. Stuedemann, J. J. Fuhrmann, H. H. Schomberg, and P. G. Hartel, "Soil carbon and nitrogen pools under low- and high-endophyte-infected tall fescue," Soil Science Society of America Journal, vol. 63, no. 6, pp. 1687-1694, 1999.

[23] A. J. Franzluebbers and J. A. Stuedemann, "Soil carbon and nitrogen pools in response to tall fescue endophyte infection, fertilization, and cultivar," Soil Science Society of America Journal, vol. 69, no. 2, pp. 396-403, 2005.

[24] J. Iqbal, J. A. Siegrist, J. A. Nelson, and R. L. McCulley, "Fungal endophyte infection increases carbon sequestration potential of southeastern USA tall fescue stands," Soil Biology and Biochemistry, vol. 44, no. 1, pp. 81-92, 2012.

[25] M. Omacini, T. Eggers, M. Bonkowski, A. C. Gange, and T. H. Jones, "Leaf endophytes affect mycorrhizal status and growth of co-infected and neighbouring plants," Functional Ecology, vol. 20, no. 2, pp. 226-232, 2006.

[26] B. L. Sutherland, D. E. Hume, and B. A. Tapper, "Allelopathic effects of endophyte-infected perennial ryegrass extracts on white clover seedlings," New Zealand Journal of Agricultural Research, vol. 42, no. 1, pp. 19-26, 1999.

[27] E. J. Peters and A. H. B. Mohammed Zam, "Allelopathic effects of tall fescue genotypes," Agronomy Journal, vol. 73, no. 1, pp. $56-58,1981$.

[28] T. L. Springer, "Allelopathic effects on germination and seedling growth of clovers by endophyte-free and -infected tall fescue," Crop Science, vol. 36, no. 6, pp. 1639-1642, 1996.

[29] C. Bertin, R. N. Paul, S. O. Duke, and L. A. Weston, "Laboratory assessment of the allelopathic effects of fine leaf fescues," Journal of Chemical Ecology, vol. 29, no. 8, pp. 1919-1937, 2003.

[30] P. M. Antunes, J. Miller, L. M. Carvalho, J. N. Klironomos, and J. A. Newman, "Even after death the endophytic fungus of Schedonorus phoenix reduces the arbuscular mycorrhizas of other plants," Functional Ecology, vol. 22, no. 5, pp. 912-918, 2008.

[31] J. A. Rudgers and S. Orr, "Non-native grass alters growth of native tree species via leaf and soil microbes," Journal of Ecology, vol. 97, no. 2, pp. 247-255, 2009. 
[32] N. S. Hill, J. G. Andrae, R. G. Durham, and D. W. Hancock, "Herbicide treatments to renovate toxic endophyte infected tall fescue pastures with 'Jesup' Maxq,' Crop Science, vol. 50, no. 3, pp. 1086-1093, 2010.

[33] D. Schlueter and B. Tracy, "Sowing method effects on clover establishment into permanent pasture," Agronomy Journal, vol. 104, no. 5, pp. 1217-1222, 2012.

[34] L. A. Weston, "Utilization of allelopathy for weed management in agroecosystems," Agronomy Journal, vol. 88, no. 6, pp. 860866, 1996.

[35] P. Phelan, A. P. Moloney, E. J. McGeough et al., "Forage legumes for grazing and conserving in ruminant production systems," Critical Reviews in Plant Sciences, vol. 34, no. 1-3, pp. 281-326, 2014.

[36] M. A. Ponce, M. J. Bompadre, J. M. Scervino, J. A. Ocampo, E. J. Chaneton, and A. M. Godeas, "Flavonoids, benzoic acids and cinnamic acids isolated from shoots and roots of Italian rye grass (Lolium multiflorum Lam.) with and without endophyte association and arbuscular mycorrhizal fungus," Biochemical Systematics and Ecology, vol. 37, no. 4, pp. 245-253, 2009.

[37] M. G. Cripps, G. R. Edwards, and S. L. McKenzie, "Grass species and their fungal symbionts affect subsequent forage growth," Basic and Applied Ecology, vol. 14, no. 3, pp. 225-234, 2013.

[38] C. Bertin, X. Yang, and L. A. Weston, "The role of root exudates and allelochemicals in the rhizosphere," Plant and Soil, vol. 256, no. 1, pp. 67-83, 2003.

[39] B. F. Tracy, D. H. Schlueter, and J. P. Flores, "Conditions that favor clover establishment in permanent grass swards," Grassland Science, 2014.

[40] T. E. Staley and D. P. Belesky, "Nodulation and root growth of forage legumes sown into tall fescue swards," Grass and Forage Science, vol. 59, no. 4, pp. 399-405, 2004.

[41] R. J. Stephenson and G. L. Posler, "The influence of tall fescue on the germination, seedling growth and yield of birdsfoot trefoil," Grass and Forage Science, vol. 43, no. 3, pp. 273-278, 1988.

[42] L. A. Weston, "Cover crop and herbicide influence on row crop seedling establishment in no-tillage culture," Weed Science, vol. 38, no. 2, pp. 166-171, 1990.

[43] P. W. Voigt, D. R. Morris, and H. W. Godwin, "A soil-on-agar method to evaluate acid-soil resistance in white clover," Crop Science, vol. 37, no. 5, pp. 1493-1496, 1997.

[44] P. W. Voigt and J. A. Mosjidis, "Acid-soil resistance of forage legumes as assessed by a soil-on-agar method," Crop Science, vol. 42, no. 5, pp. 1631-1639, 2002.

[45] M. H. Zwietering, I. Jongenburger, F. M. Rombouts, and K. Van't Riet, "Modeling of the bacterial growth curve," Applied and Environmental Microbiology, vol. 56, no. 6, pp. 1875-1881, 1990.

[46] R. C. Littell, G. A. Milliken, W. W. Stroup, and R. Wolfinger, SAS System for Mixed Models, SAS Institute, Cary, NC, USA, 1996.

[47] SAS, SAS OnlineDoc, Version 8, SAS Institute, Cary, NC, USA, 1999.

[48] T. J. Butler and J. P. Muir, "Perspective on forage legume systems for the tallgrass and mixed-grass prairies of the Southern Great Plains of Texas and Oklahoma," Crop Science, vol. 52, no. 5, pp. 1971-1979, 2012.

[49] G. J. Cuomo, D. G. Johnson, and J. Head W.A., "Interseeding kura clover and birdsfoot trefoil into existing cool-season grass pastures," Agronomy Journal, vol. 93, no. 2, pp. 458-462, 2001.

[50] D. Pańka, C. P. West, C. A. Guerber, and M. D. Richardson, "Susceptibility of tall fescue to Rhizoctonia zeae infection as affected by endophyte symbiosis," Annals of Applied Biology, vol. 163, no. 2, pp. 257-268, 2013.

[51] D. Pańka, D. Piesik, M. Jeske, and A. Baturo-Cieśniewska, "Production of phenolics and the emission of volatile organic compounds by perennial ryegrass (Lolium perenne L.)/Neotyphodium lolii association as a response to infection by Fusarium poae," Journal of Plant Physiology, vol. 170, no. 11, pp. 10101019, 2013.

[52] D. Cipollini, C. M. Rigsby, and E. K. Barto, "Microbes as targets and mediators of allelopathy in plants," Journal of Chemical Ecology, vol. 38, no. 6, pp. 714-727, 2012.

[53] T. J. Butler, J. D. Stein, S. M. Interrante, and D. P. Malinowski, "Novel approaches to establishing alfalfa-tall fescue pastures in the southern great plains," Forage \& Grazinglands, vol. 9, no. 1, 2011.

[54] D. P. Belesky, D. M. Burner, and J. M. Ruckle, "Does endophyte influence resource acquisition and allocation in defoliated tall fescue as a function of microsite conditions?" Environmental and Experimental Botany, vol. 63, no. 1-3, pp. 368-377, 2008.

[55] S. M. Mersch and A. B. Cahoon, "Biomass and tiller growth responses to competition between Ky31 and MaxQ Festuca arundinacea cultivars and response of Ky31 to exogenously applied liquid preparation of Neotyphodium coenophialum under glasshouse conditions," Grass and Forage Science, vol. 67, no. 2, pp. 299-304, 2012. 


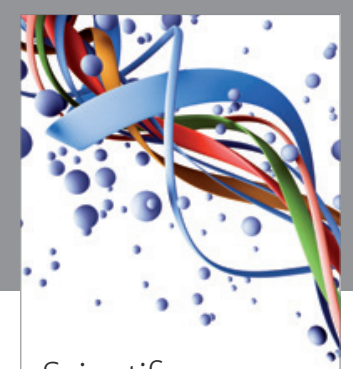

Scientifica
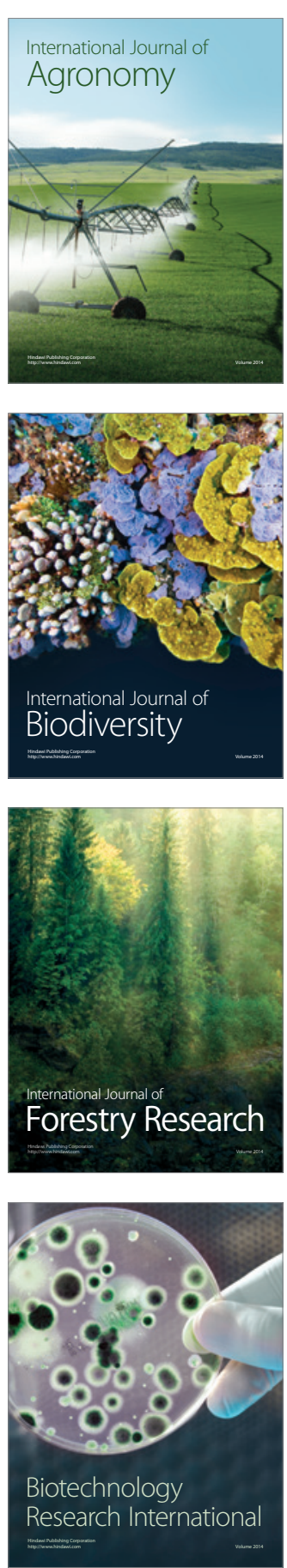
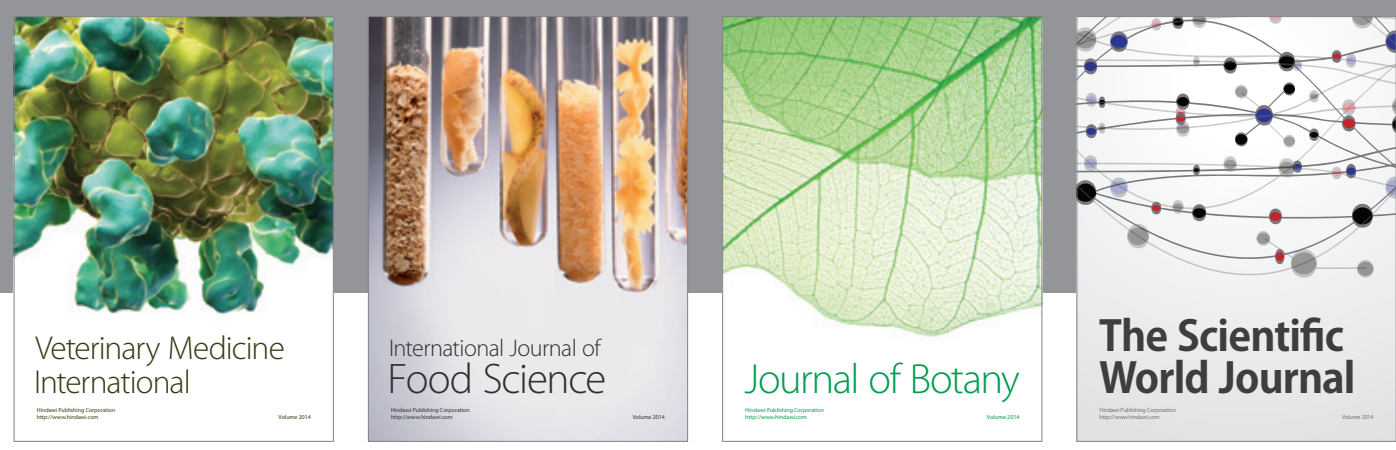

The Scientific World Journal
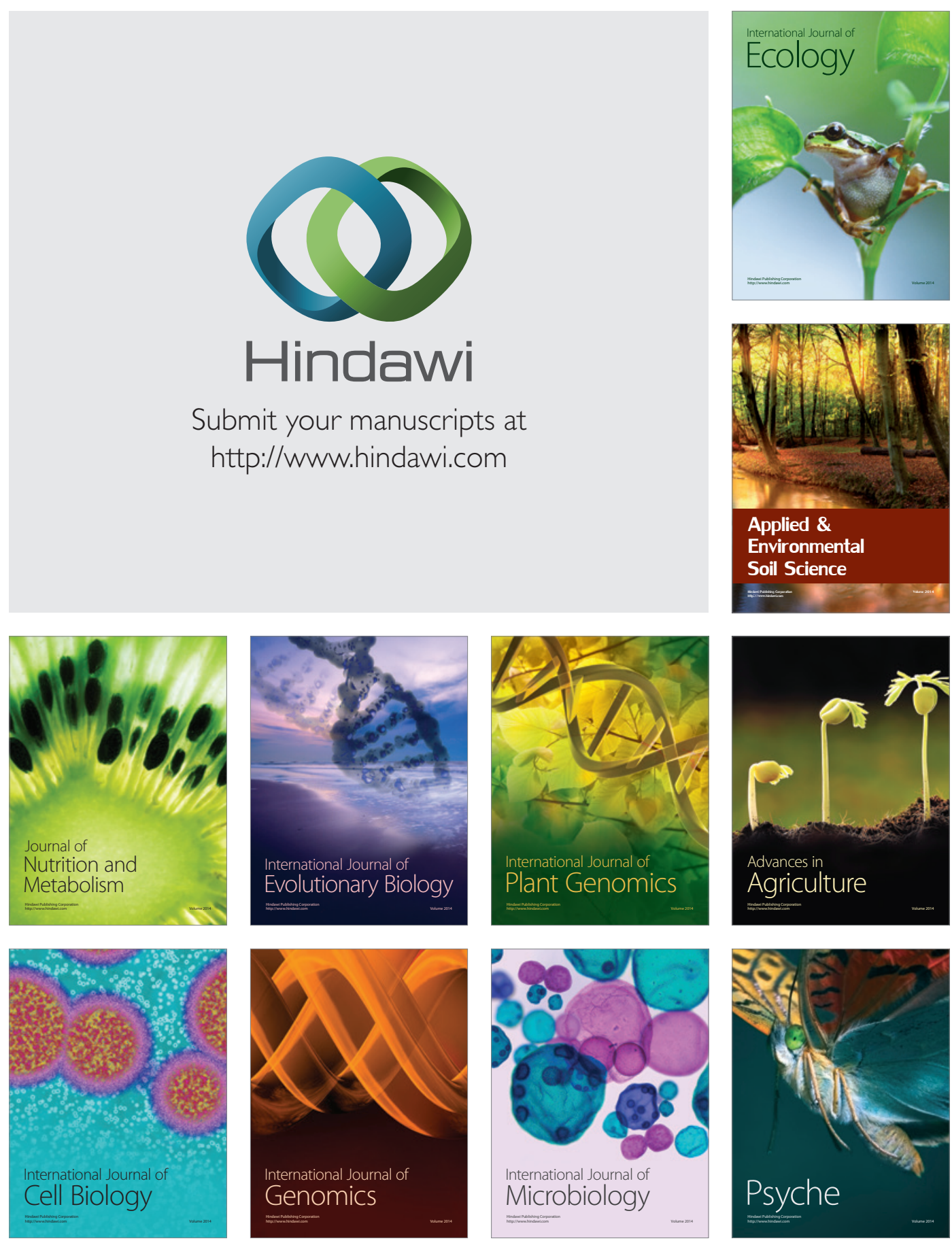